\title{
14th European Marine Biology Symposium "Protection of Life in the Sea": Summary of symposium papers and conclusions
}

\author{
O. Kinne \\ Biologische Anstalt Helgoland (Zentrale); \\ Palmaille 9, 2000 Hamburg 50, Federal Republic of Germany
}

\begin{abstract}
This last paper of the 14th European Marine Biology Symposium refers to organizational aspects of the meeting; provides a summary of the papers presented in this volume; and attempts to draw conclusions. The summary highlights essentials of the facts presented and of the interpretations offered. It has been written in order to facilitate access to the vast amount of information contained in this volume and to provide a quick overview for the non-specialist. The conclusions present a memorandum issued by the symposium participants; consider the most dangerous pollutants and the most endangered sea areas; evaluate principal criteria for assessing pollution effects, both at the individual and ecosystem levels; and discuss mechanisms of pollution control and environmental management.
\end{abstract}

\section{INTRODUCTION}

Concerned about the increasing danger to marine life in the North Sea, the Biologische Anstalt Helgoland organized the first international symposium on North Sea pollution in 1967, ${ }^{*}$ complemented by a special session on oil pollution. ${ }^{*}$ The symposium emphasized the need for more basic marine ecological research and for concerted administrative and political action aimed at monitoring and controlling man's impact upon the sea. The general consensus of the meeting was expressed in formal recommendations (Kinne \& Aurich, 1968, p. 521) subsequently forwarded to the president of ICES. The symposium participants requested that: (1) Research be encouraged into all aspects of marine pollution. (2) There should be greater interchange of information and co-ordination of research in this field. (3) Government agencies of different countries adjoining this area should be asked to co-ordinate their research and administrative efforts with a view to halting and reducing the adverse effects of pollution on ecosystems and valuable international fisheries of the North Sea and adjacent waters.

In this 14th European Marine Biology Symposium, we have again come together on Helgoland and considered basically the same topic: "Protection of Life in the Sea." What has happened in the 12 years between these two meetings? Has there been much

* Proceedings published in Helgoländer wiss. Meeresunters. 17, 1-530 (1968)

** Proceedings published in Helgoländer wiss. Meeresunters. 16, 285-384 (1967) 
progress in pollution assessment and control? Yes and no. Governments have provided considerable funds for pollution research and there have been numerous hearings, meetings and conventions. In many cases, pollutant release into lakes and rivers has been reduced and increasingly controlled. This has led to measurable improvements in the water quality of several rivers and, in some instances, to ecosystem recovery. However, coastal waters and open sea areas still receive heavy pollutant loads. Often subject to international interest conflicts and less readily controllable than inland waters, the sea has remained a primary problem area. Great difficulties still exist in distinguishing natural variability from pollution effects, in developing ecologically adequate methods for assessing pollution stress, and in selecting sound early-warning criteria for predicting impact effects at the individual and ecosystem level.

This final paper of the symposium refers to organizational aspects pertaining to the meeting; provides a summary of the papers presented in the volume; and draws conclusions based on symposium discussions and papers, as well as on pertinent literature.

\section{ORGANIZATIONAL ASPECTS}

The history of International Helgoland Symposia has shown a combination of formal paper presentations and informal sessions to provide a favourable compromise: the former facilitate an uninterrupted flow of definite data and argumentation and thus present the necessary solid data for the informal sessions, but they often suffer from insufficient opportunities for detailed discussion, from lack of dynamics, and from too many participants. Restricted to a smaller, selected group, informal sessions facilitate free exchange of ideas and in-depth discussions, but they tend to have shortcomings in professional breadth and solid data, and to suffer from lack of the discipline required for a logical flow of thoughts and argumentation.

In addition to the combination of formal and informal sessions, poster sessions (where pertinent, written recommendations of participants) and the attempt of the symposium president to formulate a summary and to draw conclusions are considered desirable for optimizing the outcome of the meeting and for facilitating access to its published proceedings for a wide readership. In view of the increasing significance of European Marine Biology Symposia, our experiences and considerations may be useful to future EMBS organizers.

In order to prepare the symposium properly, to cover all essential scientific aspects and to reduce undesirable topical overlap and repetition, we proposed a number of review topics and suggested general outlines for their preparation. After soliciting advice from numerous colleagues, introductory speakers were selected and invited to review the topics. The introductory papers are intended to provide a broad general platform for, and to put into wider perspective, a larger number of topic-related short papers. The invited introductory speakers were Drs G. W. Bryan, J. Clark, W. Ernst, W. Gunkel, P. Korringa, J. R. Lewis, T. J. Pandian, T. H. Pearson, D. J. Reish, C. J. Sindermann and D. S. Woodhead.

Two basic terms used in environmental protection are often applied, defined and interpreted in different ways. In an attempt to provide a common conceptual basis for the symposium it was considered desirable, therefore, to suggest definitions for "pollution" 
and "environmental management" prior to the meeting. The definitions suggested are as follows:

Pollution: human activities causing negative effects on health, resources, amenities or ecosystems (Kinne, 1968). "Negative effects" imply demonstrable impairment. In regard to health, such impairment involves a reduction in rates of growth, reproduction and survival, as well as in impact endurance or general well-being; in regard to resources and amenities, it involves a decrease in their capacity to support man (decrease in nutrients, raw materials, recreational value, aesthetic satisfaction); in regard to ecosystems, it involves a diminution of those funtions and structures which are essential for supporting long-term human existence.

Environmental management aims at compensating for pollution: at the protection of nature from critical, man-made damage. It requires the judicious, responsible application of science and technology for protecting and controlling those properties of areas, species, resources and/or ecosystems which are considered absolute requirements for their continued support of civilized human societies. Since our present knowledge is insufficient for an exact definition of such properties, maintenance of maximum possible organismic diversity and of natural conditions is considered desirable. In the face of critical man-made impact, a large diversity of gene pools and the conservation of ecologically important habitats are expected to act as "safety valves" and stabilizers. Environmental management requires international and interdisciplinary cooperation in planning and controlling.

\section{SUMMARY OF THE PAPERS PRESENTED}

This summary attempts to highlight essentials of the information presented and of the interpretations offered. It has been written in the hope of facilitating access to the vast amounts of data and detail contained in the 62 papers comprising this volume and to provide a quick overview for the non-specialist.

Where considered necessary or desirable for the benefit of the reader the actual sequence of papers has been changed somewhat. Not all papers read at the symposium have been included in this volume. The editors rejected papers which were not submitted in time or suffered from insufficient relevance or quality. According to topics, the papers are grouped in 8 sections: (1) heavy-metal pollution; (2) radioactive materials; (3) oil, oil dispersants and related substances; (4) pesticides and related compounds; (5) industrial and domestic pollution; (6) pollution due to other sources; (7) environmental management and evaluation; (8) management of areas, species and ecosystems.

\section{Heavy-metal pollution}

The sessions on heavy-metal pollution were chaired by M. Barnes, C. G. Bookhout, K. Lüning and J. Sarvala. G. W. Bryan introduced the topic with an authoritative, explicit review (pp. 6-25). Man-made metal pollutants enter the sea via rivers, outfalls, atmospheric fallout, dumping, marine mining and drilling, as well as from ships. Of the metals concerned, mercury, cadmium and lead are considered potentially most dangerous to public health, but copper, zinc, silver and chromium may also be detrimental to marine organisms. Estuaries, often used by industry for heavy-metal disposal, are 
especially endangered. They tend to accumulate high heavy-metal concentrations in their sediments and thus may sustain continued water pollution even in the absence of further external metal input. Accumulation and trapping make estuaries highly unsuitable as receivers of heavy-metal pollutants.

The intensity and capacity for bioaccumulation and excretion of metals varies with the organisms and the metal species concerned; they depend on physiological state, metabolic rate and environmental as well as nutritional circumstances. Bioaccumulation along food chains is augmented if a predator feeds selectively on non-regulating metal accumulators; it attains maximum values in such predators when they are non-regulators themselves. While animals may contain higher metal concentrations than their diet, general bioamplification from phytoplankton to fishes and marine mammals has thus far been shown only for methyl mercury. Organismic indicators of metal contamination should be good accumulators (non-regulators), of reasonable size, reflect changes in the biological availability of ambient metals, be widely distributed, common in space and time, accessible, easily recognized, fairly stationary, and suitable for experimentation. There is no universal indicator organism. For proper assessments of pollution stress, a combination of several key organisms should be used (e.g. seaweed, filter-feeder, deposit-feeder).

While excessive concentrations of heavy metals have been shown to affect life span, rates of metabolism, growth and reproduction, as well as capacities for stress compensation, detailed analyses of functional and structural consequences are rare (see Theede p. 27) and so are definite studies on non-genetic adaptation. It remains difficult to distinguish between normal, natural metal concentrations in the sea and man-made additions, and to relate field-observed pollution effects to specific metal pollutants. While an obvious preliminary to such identification, even residue analysis requires care to make it specific. Useful are differential tolerance tests - especially when based on genetic tolerance differences - and reciprocal transfer of organisms from polluted to unpolluted waters. Bryan concludes that there is little or no evidence for deleterious effects of heavy metals on marine mammals, and - with the exception of the Minamata disease - for permanent metal poisoning due to seafood poisoning in man.

H. Theede's paper (pp. 26-35) provides further support for the fact that cadmium effects on marine invertebrates depend on the intensity of simultaneously effective environmental factors such as temperature and salinity. However, the modifying effects of these factors tend to decrease after long-term exposure. The high capacity of adult Mytilus edulis for accumulating heavy metals renders them suitable for monitoring purposes. Mussels from the sea bottom often tend to contain more Cd than their conspecifics on piles. While biological half times of $\mathrm{Cd}$ in Carcinus maenas and $M$. edulis range between $1 \frac{1}{2}$ weeks and about 2 months, vertebrates, which can store large amounts of heavy metals in liver and kidney (metallothionein binding), exhibit Cd half times of months or years.

Combined heavy-metal and salinity effects have been analyzed by E. Gould (pp. 36-46) and K. H. Røed (pp. 47-58). Gould reports increased enzyme activity in the lobster Homarus americanus after 30-day cadmium exposure $\left(6 \mu \mathrm{g} \mathrm{l}^{-1}\right)$. The major overall effect of sublethal $\mathrm{Cd}$ concentrations in lobsters was increased glycolysis - an augmented expenditure of energy reserves characteristic of stress compensation processes. Gould concludes that her findings parallel those of Theede, who established an increased gross 
energy demand in cadmium-fed Mytilus edulis larvae, and those of Price \& Uglow (see below), who report augmented heart-beat rates in cadmium-exposed Crangon crangon. Low-salinity stress caused a pronounced decrease in enzyme activity in most lobster tissues examined. Røed found low salinity, in the presence of cadmium, to retard growth rates, to prolong time to sexual maturity, and to reduce body size at maturity in long-term experiments ( 3 generations) on the polychaete Ophryotrocha labronica. Price \& Uglow (pp. 59-67) report increased heart and scaphognathite activities in Crangon crangon after acute $(30 \mathrm{~min})$ exposure to supra-natural levels $\left(1-20 \mathrm{mg} \mathrm{l}^{-1}\right)$ of $\mathrm{Cd}_{\mathrm{r}} \mathrm{Cu}$ or $\mathrm{Zn}$. Unspecific to the metals, the functional significance of these responses remains to be analysed; they may simply convey that the shrimp are able to perceive the increased metal concentration.

According to N. Scholz (pp. 68-78), in Mytilus edulis the gills are primary sites of cadmium uptake, while the mid-gut gland carries the main body load and shows the highest concentration of $\mathrm{Cd}$. Up to $100 \mu \mathrm{g} \mathrm{Cd} \mathrm{l}^{-1}$, cadmium uptake into the mussels' soft body is neither regulated nor limited, but appears to follow simple diffusion dynamics. Uptake and loss measurements indicate equilibrium attainment under natural habitat conditions with a concentration factor of 30,000 . There seem to be differences in the functions of vertebrate metallothioneins and corresponding $M$. edulis proteins. In the latter, the formation of metallothionein-like proteins cannot sufficiently account for the high Cd tolerance of the mid-gut gland. Cd loss following mussel transfer to uncontaminated natural sea water is exponential; biological half lives vary between 14 and 29 . days.

Heavy-metal effects on marine plants are considered by U. Rabsch \& M. Elbrächter, H. Kayser \& K.-R. Sperling and J. W. Markham et al.

In the diatom Coscinodiscus granii, Rabsch \& Elbrächter (pp. 79-88) recorded slight

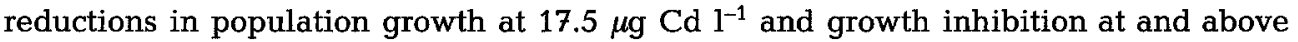
$20 \mu \mathrm{g} \mathrm{Cd} \mathrm{I}^{-1}$. At sublethal levels, heavy-metal $(\mathrm{Cd}, \mathrm{Zn})$ uptake rates and effects depend on the physiological state of the cells. Just prior to division cells were more resistant than shortly after division. Dead cells contained much higher $\mathrm{Cd}$ and $\mathrm{Zn}$ concentrations than living ones. While this may indicate active reduction of metal uptake by healthy cells, it may also be due to cell-surface enlargement (frustule disruption) in dead or dying cells. Carbon fixation was negatively affected by ambient $\mathrm{Cd}$ concentrations as low as 1.5 to $9.0 \mu \mathrm{g} \mathrm{Cd} \mathrm{I}^{-1}$, i. e. at levels considerably below those previously reported to affect diatoms.

The dinoflagellate Prorocentrum micans, a common North Sea plankter, responds very sensitively to increased ambient $\mathrm{Cd}$ levels and hence appears to represent a good indicator organism. Kayser \& Sperling (pp. 89-102) found significantly lowered multipli-

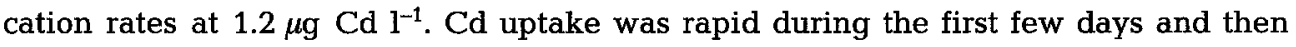
decreased somewhat during exponential growth; it increased again in dying cultures, suggesting breakdown of regulatory mechanisms or augmentation of adsorbent surfaces. Structural modifications due to Cd stress were seen in the brittleness of Lugol-fixed cell walls. Standard Cd content in control cells was $2.7 \mu \mathrm{g} \mathrm{g}^{-1}$ dry weight.

Markham et al. (pp. 103-110) exposed 24-mm diameter discs punched out of a single Ulva lactuca plant to different $\mathrm{Cd}$ concentrations under continuous-flow conditions. In principle, this method seems to hold much promise in the development of easy-to-apply standard procedures. While $U$. lactuca is quite sensitive to $\mathrm{Cd}$, its uptake rates are 
relatively slow; termination of Cd exposure results in quick metal loss. Survivors show little or no long-term after-effects. These properties and the life span of less than a year render $U$. lactuca - in contrast to such algae as Laminaria - of little value as bioindicator for metal pollution. At ca. $0.3 \mathrm{ppm} \mathrm{Cd}$ growth is sharply reduced; $4.5 \mathrm{ppm} \mathrm{Cd}$ is lethal within 6 days. Plants exposed to $0.7 \mathrm{ppm} \mathrm{Cd}$ for up to 3 days produced viable gametes 7 days after termination of $\mathrm{Cd}$ exposure.

K. Essink (pp. 111-121) analysed mercury pollution in the Ems estuary which until 1975 received several tons of this metal each year. Horizontal surveys reveal strong local sediment enrichment near the discharge point. Vertical $\mathrm{Hg}$ distribution was in accordance with local deposition rates. While the fish Zoarces viviparus contained significantly increased $\mathrm{Hg}$ levels, the free water did not reveal a significant increase. Essink's paper underlines the need for including the biota in a detailed assessment of the pollution status of a given area.

\section{Radioactive materials}

Under the chairmanship of M. Barnes, this brief session was introduced by D. S. Woodhead (pp. 122-137). Primarily concerned with safe-guarding human health, the reviewer centres on dose limits for members of the general public, control mechanisms of radioactive marine pollution and radiation exposure of fish populations. Radionuclides are a natural component of the marine environment; hence, attention and concern focus on the release of man-made radioactive wastes, especially into estuaries, coastal waters and semi-enclosed sea areas. We must know their quantities, qualities and major ecological consequences, as well as their potential routes back to the human population via seafood.

Control procedures aim at minimizing the exposure of man and marine organisms to levels sufficient for protection and practicable in terms of technology and economy. Of the three control mechanisms considered - point of discharge control, specific activity approach, and critical pathway analysis - Woodhead stresses the advantages of the latter and exemplifies this by describing the controls applied to discharge into the north-east Irish Sea from the radioactive fuel reprocessing plant at Windscale.

The critical pathway analysis treats each disposal situation separately with the objective of identifying and quantifying the routes which could potentially result in undesirable human exposure, e.g. via seafood or depositions on beaches. After considering the radiation to which fish populations are exposed, Woodhead concludes that the dose rates at Windscale are at least one order of magnitude below those expected to cause effects under controlled laboratory conditions and almost two orders of magnitude below those necessary to have an effect on reproduction.

Hoppenheit et al. (pp. 138-152) studied uptake and effects of americium 241 in the brackish-water amphipod Gammarus duebeni duebeni. Using ${ }^{241} \mathrm{Am}$ concentrations several orders of magnitude above those permissable in the sea in terms of public radiation protection, they found that $61 \%(30-94 \%)$ of the total body burden is fixed in the exoskeleton (exuvia). Since the body burden remained constant over the $\mathrm{pH}$ range 8.0 to 6.5 , even though concentrations in the ambient water changed markedly, the concept of a concentration factor is felt to be in need of re-examination. It is proposed to define a factor on the basis of environmental and chemical parameters which determine the physiologically available fraction of the actinides. 
Strack et al. (pp. 153-163) found the marine flagellate Dunaliella bioculata suitable for assessing radioactive contamination due to ${ }^{3} \mathrm{H}$ bound to organic molecules. Released from nuclear facilities, most ${ }^{3} \mathrm{H}$ is finally dispersed into the sea and a significant amount may enter living organisms. Of the 10 tritiated precursors examined, all were taken up by $D$. bioculata. The total amount of tritiated water released into the sea is rapidly increasing. Since organic tritium could be accumulated and transported in the food chain, it presents a potential danger to public health (e.g. genetic damage). The authors plead for critical analyses of the fate of ${ }^{3} \mathrm{H}$ in marine organisms.

\section{Oil, oil dispersants and related substances}

Introduced by W. Gunkel \& G. Gassmann (pp. 164-181) in sessions chaired by R. Brinkhurst, D. J. Gould, G. Rheinheimer and H. von Westernhagen, this topic attracted considerable attention at the meeting - a fact paralleling the unique interest in oil pollution shown over the last few decades by the general public, administrators and politicians. Such special attention is understandable because of the dramatic and easyto-observe impact of large tanker accidents, especially on large-sized organisms such as birds, and a variety of intertidal plants and animals, but also on fisheries, coral reefs, recreational beach areas and marinas. Nevertheless, pollution effects due to oil have thus far remained quite limited in space and time. None of the criteria usually employed for assessing pollution stress - e.g. species diversity and abundance, rates of growth and reproduction have indicated measurable, severe long-term damage traceable to oil effects. The major reason for this is that oil - itself a product of nature - is amenable to rapid natural degradation by living organisms (especially microorganisms) and a variety of physical processes (especially water movement and mixture with inorganic materials).

Methods for analysing oil components in sea water have attained a high level of sophistication, reproducibility and exactness - to a considerable degree due to significant advancement in glass-capillary gas chromatography. This has facilitated recent research into sublethal long-term effects of individual hydrocarbons and created concern that long-lived hydrocarbons may affect biochemical aspects of ecosystem integration and chemical communication among organisms. Our present knowledge is inadequate for evaluating, in sufficient detail and depth, the ecological significance of "pollutionmade pheromones" or the potential interference of oil-degradation products with biological effects of natural pheromones. According to Gunkel \& Gassmann, there is no increased risk of cancer due to seafood containing polycyclic aromatic hydrocarbons derived from crude oil. Great gaps remain in our knowledge on atmospheric hydrocarbon input, in-situ microbial degradation rates, and whether pelagic oil can reach the deep-sea bottom.

Oil dispersants and related substances create a number of additional, not yet fully understood ecological problems. In any case, only low-viscosity oils can be dispersed and the dispersants must be applied quickly after oil release. Major disadvantages of oil dispersants include: retardation of evaporation of volatile oil components; potentially toxic effects on the biota; restriction to local applicability and high costs. Consequently, a number of oil-pollution control measures have concentrated on mechanical oil collection and removal. 
Pollution effects of the "Amoco Cadiz" oil spill are considered by C. den Hartog \& R. P. W. M. Jacobs (pp. 182-191), L. Cabioch et al. (pp. 192-208), A. Beslier et al. (pp. 209-224) and J. F. Samain et al. (pp. 225-235). In all cases, the rather dramatic immediate primary effects (e.g. heavy reduction in abundance and changes in distribution) turned out to be reversible, in some cases within weeks, months or a few years. In others, repopulation dynamics are not yet fully predictable. Baseline knowledge on the status of some marine communities prior to the "Amoco Cadiz" disaster has turned out to be very important for effect evaluation. Since baseline data are largely lacking in other related areas, a critical analysis of long-term effects is not yet possible. The first-named authors recorded profound but selective effects on eelgrass communities. While some animals remained apparently unaffected, others (e.g. amphipods) disappeared. Some recovered rapidly but re-establishment of filter-feeders has not yet been observed. In the sublittoral benthos, Cabioch et al. found the oil to affect communities on fine rather than mixed sediments. The spill selectively damaged a limited number of species, mainly crustaceans, molluscs and the echinoderm Echinocardium cordatum. Destruction of dominant Ampelisca populations in fine sands led to marked decreases in biomass and production. Repopulation is expected to be difficult due to community isolation. Secondary effects included a proliferation of polychaetes. Concentrating on hydrocarbon distribution in sublittoral sediments, Beslier et al. recorded oil deposition near coastal areas hit by the slicks and subsequent redistribution of particulate and sediment-adsorbed oil towards areas of low hydrodynamic energy which favour fine-particle deposition. Both oil deposition and redistribution depended essentially on local hydrodynamics, especially waves and tidal currents. Samain et al. conducted an ecophysiological survey on zooplankton, comparing an oil-polluted estuary with a non-polluted counterpart. Measuring two digestive enzymes (amylase, trypsin) the trophic interrelations between zooplankters, mesoplankters and some other organisms are analysed and used for pollution assessment. It was possible to distinguish: an immediate impact of oil pollution lasting 15 days offshore and 30 days onshore; a secondary effect preventing exogenous species from settling; a tertiary effect manifesting itself after 1 year in subsurface-living organisms upon rest-oil release from the very polluted area.

H. M. Platt \& P. R. Mackie (pp. 236-245) investigated the presence, distribution and long-term fate of hydrocarbons (largely due to fuel oil released from now abandoned whaling stations) in the Antarctic; they further substantiated the fact that degradation of oil and its components is retarded by low temperatures. The remote Antarctic environment is not immune from global anthropogenic hydrocarbon sources. Pollution effects established in temperate seas cannot without further qualification be assumed to pertain to polar regions.

Methodological aspects of oil pollution assessment have been dealt with by W. P. Davis et al. (pp. 246-256), D. C. Malins et al. (pp. 257-271) and E. Zeeck (pp. 272-277). Davis et al. propose the "integrated zonal method of ecological impact assessment" which combines rapid geomorphic/geological mapping with quantitative ecological and chemical sampling. Their "Vulnerability Index" is intended to assist in devising firstline defense measures against oil spills. Malins et al. describe and discuss techniques for hydrocarbon analysis and new methods for analysing polar aromatic components, and Zeeck demonstrates the usefulness of fluorescence microscopy for determining and localizing oil components in living organisms. 
According to M. N. Moore et al. (pp. 278-291), Mytilus edulis has a limited capacity for metabolizing organic xenobiotics. The resulting components of the microsomal detoxication/toxication system require further investigation. Experimental evidence showing induction of microsomal enzymes by foreign compounds demonstrates the possibility of using this phenomenon in the development of indices of response to contamination by certain organic xenobiotics, such as oil-derived aromatic hydrocarbons. Possibly, enzymatic induction could provide an index of responses to contamination by certain organic xenobiotics. O. G. Mironov (pp. 292-296) reports that the quantity and composition of hydrocarbons determined in $M$. galloprovincialis depends on season and sea-water quality. Mussels filtering sea water polluted with oil and oil products accumulate, transform during gut passage and excrete oil pollutants in faeces and pseudofaeces; both contain a higher percentage of aromatic compounds than the oil initially present in the ambient water. When fed contaminated mussels, the crab Eriphia verrucosa accumulates oil pollutants in its whole body.

M. A. Vashchenko (pp. 297-300) established long-term effects of sublethal ambient hydrocarbon concentrations in the sea urchin Strongylocentrotus nudus which turned out to be highly sensitive to oil pollution. At sublethal hydrocarbon levels, defective gametes are produced which give rise to non-viable offspring. The physiological basis of the damage requires further investigation.

\section{Pesticides and related compounds}

In sessions chaired by B. I. Dybern and W. Klepal, this topic was introduced by W. Ernst (pp. 301-312). At present, man's increasing chemical industry produces and distributes more than 60,000 common chemicals, and new ones are added at the rate of several hundred per year. Foreign to the marine environment, many of these potentially dangerous substances ultimately reach the sea, threatening the life in coastal waters, especially in estuaries. Most of the man-made organic chemicals thus far identified in the sea are chlorine-containing pesticides and technical products. Presumably, a large portion has not yet been detected due to lack of suitable sensitive and specific analytical methods. The considerable structural multiplicity of the large number of chemicals involved escapes individual determinations and calls for practicable measurement procedures and suitable criteria. Essential physico-chemical, biological and ecological parameters must be combined for estimating and defining permissable safe levels.

Ernst considers particularly the bioconcentration and biomagnification of the pesticides concerned, their metabolic modifications within the living organisms, and the significance of toxicity measurements. For proper assessments of bioconcentration (uptake directly from the ambient water or indirectly via nutrients) test organisms must be studied under steady-state conditions. In general, the bioconcentration potential increases with decreasing pollutant solubility. However, presently available solubility values as low as required for ecologically meaningful evaluations are difficult to determine and the results thus far obtained are often contradictory. Biomagnification (pollutant accumulation in the food chain) requires more time to manifest itself than for bioconcentration to become apparent. Pronounced biomagnification of persistent pesticide compounds is likely to occur with increasing half lives of the substances concerned. $\mathrm{LD}_{50}$ toxicity tests have a number of shortcomings, especially these: death is a crude end 
point to measure and the time involved is too short to assess ecologically relevant consequences.

Although we now have a number of highly specialized and sophisticated analytical methods at hand for measuring pesticides and related compounds in sea water, sediment and organisms, it is a long way before we can predict ecological consequences of pesticide pollution and determine exact safety factors.

H. Goerke \& W. Ernst (pp. 313-326) studied accumulation and elimination of ${ }^{14} \mathrm{C}-\gamma$ $\mathrm{HCH}$ in the polychaete Nereis virens. They report bioconcentration factors of 400 and 440 at $6{ }^{\circ} \mathrm{C}$ and $16^{\circ} \mathrm{C}$, respectively (500 and 410 based on total radioactivity). These are in the upper range of concentration factors known for other aquatic invertebrates. $N$. virens required 14 days at $6{ }^{\circ} \mathrm{C}$ and 10 days at $16^{\circ} \mathrm{C}$ to achieve equilibrium with the ambient pollutant concentration of $1 \mu \mathrm{g} \mathrm{l}^{-1}$. Pollutant elimination proceeds exponentially.

M. E. Christiansen \& J. D. Costlow Jr. (pp. 327-332) and W. A. M. Courtney \& W. J. Langston (pp. 333-339) report on pesticide contamination experiments with crabs and fish, respectively. According to the first-named authors, 10 ppb Dimilin ${ }^{*}$ known to interfere with chitin formation in the cuticle of insect larvae and offered on the U.S. market for insect control - causes death in nearly $100 \%$ of the decapod (Rhithropanopeus harrisii) larvae tested after 3 days. In brackish water, Dimilin breaks down only slowly: it took about 8 weeks before a $10 \mathrm{ppb}$ concentration degraded to levels not lethal to the crab larvae. Since Dimilin has also been shown to be highly toxic to the larvae of other estuarine crustaceans, the authors warn against use of Dimilin for insect control in estuarine areas. Courtney \& Langston exposed juvenile turbot Scophthalmus maximus to polychlorinated biphenyls (Aroclor 1254). They report contamination from sea water with concentration factors of $10^{4}$ and $10^{3}$ for liver and muscle, respectively. However, benthic individuals probably become contaminated from estuarine and coastal sediments which harbow these pollutants: fish muscle residues were similar to those of test sediments containing 1 or $60 \mathrm{ppm}$. Body loads of PCB which were less than the content of the diet $(20 \mathrm{ppm})$ were reduced in fish fed with uncontaminated food but not in starved individuals.

\section{Industrial and domestic pollution}

These sessions were chaired by B. I. Dybern, J. D. George, W. Klepal and J. B. Pearce. Reviewing our present knowledge on the effects of pulp and paper industry wastes discharged into the sea, T. H. Pearson (pp. 340-365) concludes that large amounts of such wastes increase the oxygen demand of the receiving waters and thus may significantly distort oxygen, nutrient and carbon budgets in the local pelagic and benthic biota. In contrast, the direct toxicity of these waters tends to be minimal. After pollutant removal recovery is usually quick and pronounced. Where the discharge of pulp and paper wastes is adequately controlled, these pollutants need not pose a serious hazard to marine life. Providing carbon inputs do not exceed the carrying capacity of the receiving ecosystem, they may eventually even enhance the local commercial fishery yield.

In order to prevent inputs exceeding the safety limit, biological long-term monitoring is necessary for effluents and receiving waters (physico-chemical properties of water 
and sediment, population structure and dynamics, physiological state of individuals). Given a baseline knowledge of receiving water and biota, routine monitoring could be based on recording a few key variables such as redox potential of sediments and states of major benthic populations. In the near future the monitoring of biochemical changes (e.g. enzyme activities) in selected species should provide additional, quick-to-measure, early-warning criteria. The succeeding speaker, R. S. Millner (pp. 366-376), exemplifies some of the above statements: the Swale, a tidal channel on the east coast of England, has received pulp and paper mill wastes over the past 90 years. The most noticeable effects were reduced levels of dissolved oxygen and increased organic loading of the sediment. Increases in the local biomass without significant changes in species composition of the macrobenthos demonstrate the ability of the receiving soft-bottom biota to tolerate high organic inputs.

Locally limited, apparently largely reversible eutrophication effects of domestic and industrial wastes have also been reported by D. J. Reish (pp. 377-383), D. S. McLusky et al. (pp. 384-392) and A. Kocataş \& R. Geldiay (pp. 393-400). With the continuing migration of people to metropolitan centres adjacent to the sea, Reish foresees increasing difficulties in controlling and eliminating their wastes. Periodic monitoring of domestic sewer discharges in southern California (USA), in some instances for nearly 25 years, has demonstrated the importance of the local benthos as indicator of pollution effects. While large waste amounts tend to damage the benthos within 2 to 4 years, only 1 year is required for recovery after pollutant removal. In the Scottish Forth estuary, which receives domestic and industrial (petrochemical and distilling) wastes, McLusky et al. established a reduction in faunistic diversity in the most polluted parts of the estuary with oligochaetes being the sole inhabitants of the mudflats. Close to a petro-chemical outfall, annelids were completely absent. In the least polluted areas, the numbers of oligochaetes diminished while the number and diversity of other macrofaunal components increased. Similarly, Kocataş \& Geldiay recorded increasing species diversity (total: 112 species) and abundance with increasing distance from heavy, untreated domestic pollution outfall.

Health conditions and distributions of flounder Platichthys flesus and smelt Osmerus eperlanus served Köhler \& Hölzel (pp. 401-414) as criteria for assessing pollutant loads in the Elbe estuary (FRG). Discolouration and structural degeneration of the liver, as well as successive desquamation defects of the intestinal mucosa, are interpreted as consequences of environmental toxins. Major causes appear to be toxic compounds in the food consumed. In addition, periodical oxygen deprivation and fluctuating peaks of toxic nitrite concentrations are held responsible for long-term distributional shifts toward the river mouth. Köhler \& Hölzel conclude that even the Elbe estuary, which is less polluted than the area between Hamburg and Glückstadt, fails to offer health-supporting conditions for flounder and smelt.

\section{Pollution due to other sources}

Under the chairmanship of V. Dethlefsen, this session considered the potential ecological impact of dam-building, power-plant discharges and deep-ocean mining. While the data at hand are insufficient for detailed critical evaluation and, especially, for 
reliable forecasting, present knowledge indicates that ecological effects will tend to remain restricted and largely reversible.

T. J. Pandian's review (pp. 415-421) lists the following dangers of dam-building: decrease of water discharge into the sea accompanied by reductions in estuarine and coastal nutrient concentrations and hence in plankton and fish production; reduced (changed) mud and silt deposition affecting life in the benthos and leading to coastal retreat; hindering of migrations, especially in fishes and crustaceans. Where extreme, the latter can cause extinction of upstream populations. Large dam-building projects may result in climatic changes. Major benefits of dam-building include hydro-electric power generation, support of agriculture and industry, as well as potential improvements in navigation, irrigation, sport and recreation.

According to J. M. Capuzzo (pp. 422-432), the impact of power plants on plankters depends on the degree and duration of the stress encountered due to pumping of cooling water; physico-chemical interaction of discharge and receiving waters; the amount of chlorine (or other biocides) added to cooling waters for fouling control; and properties of the receiving water which affect toxicant formation due to chlorination. Detrimental effects of condenser passage vary with specific features of power-plant design, operational procedures and siting. In spite of reduced survival rates of zooplankters due to mechanical, thermal and biocidal stresses, there were no alterations in secondary production rates in the receiving waters. Obviously, the percentage of zooplankton affected is too small in comparison with the high reproductive rates of unaffected zooplankters. The most detrimental effects appear to be reductions in survival and/or growth of meroplankters. In order to minimize detrimental effects, Capuzzo recommends: (1) careful siting of new coastal power plants aiming at adequate effluent dilution; (2) adjustment of thermal increases to seasonal ambient temperatures and thermal tolerances of dominant zooplankters; (3) low-level chlorination combined with dechlorination and/or rapid cooling-water dilution.

Deep-ocean mining of manganese nodules (R. E. Burns, pp. 433-442) leads to heavy impacts at the sea floor and at the sea surface. At the sea floor, the collector removing the nodules causes almost total destruction of benthic biota and heavy sediment disturbances along the collection track, emitting a cloud of resuspended material: the benthic plume. At the sea surface discharge of unwanted material produces a surface plume. Photography reveals a zone of heavy resedimentation of about $100 \mathrm{~m}$ on each side of the collection track. Within this zone, resedimentation may bury benthic animals and modify sea-floor properties. Some material resuspended by the collector is carried away in the plume. The ultimate degree of these disturbances depends, of course, on extent and duration of actual mining.

The surface plume tends to reduce primary production (diminished illumination), but this effect is extremely localized and non-persistent. The plume ages and disperses quickly. C. Schütt \& J. C. G. Ottow (pp. 443-451) warn that large-scale deep-sea mining - expected within the next 10 to 30 years - may lead to microbial lysis of deep-sea nodules. Manganese nodules buried by resettled sediment may be dissolved, liberating mobile Mn (II), Fe (II) and trace elements. The authors call attention to possible economical and ecological consequences and recommend critical examination before starting commercial deep-sea mining. 


\section{Environmental management and evaluation}

These sessions were chaired by L. Hagerman, J. B. Pearce, H. Thiel and G. Uhlig. In his revealing and critical introductory paper, J. R. Lewis (pp. 452-466) discusses options and problems of environmental management and evaluation. Largely based on lethal and sublethal effects recorded in experiments, anti-pollution measures have thus far centred on controlling effluent inputs, while the ultimate criteria for environmental evaluation are organismic in-situ responses at the population and community levels. However, here natural and man-made impacts tend to cause similar, and hence often indistinguishable consequences. While short-term sublethal studies proliferate, many data remain uninterpretable except in cases of gross disturbance: "Not the least of our problems as biologists is that which is met so often in environmental debates, of trying to persuade society to balance largely immeasurable attributes against hard economic facts or predictions'" (p. 453).

Lewis considers two principal aspects: selective protection of areas, habitats and species from obvious misuse and human pressure and the more general attempts to maintain the overall quality of the aquatic environment. The former aspect is the more obvious and largely practicable component of environmental management. With respect to the latter it becomes "disconcertingly apparent that broadscale field effects are less convincingly demonstrable than was expected" (p. 456). Present management procedures then remain, at best, largely restricted to controlling obvious man-made habitat destruction, persistent gross pollution and over-exploitation. The more subtle threats of chronic pollution do not yet reveal clearly demonstrable negative effects on the scale feared a decade ago. If, in spite of concerted efforts, it is still difficult to demonstrate chronic effects on communities, does this not indicate that such effects are negligible? "If we answer negatively and argue convincingly about timescales or the need to 'play safe' until we know for certain (will we ever?) we must also demonstrate, even more convincingly, that future research will be in the most relevant areas" (p. 464).

Methods for biological monitoring were applied and tested by O. K. Sandnes \& B. Gulliksen (pp. 467-472), H. Christie (pp. 473-483), R. G. Hartnoll \& S. J. Hawkins (pp. 484-494) and J. A. Berge (pp. 495-506). In the first two papers, underwater stereophotography was found to be a useful monitoring tool. Non-destructive but selective (small or hidden organisms cannot always be observed), this method - combined with field experiments - revealed to Sandnes and Gulliksen that sea urchins appear to act as "key organisms" * in structuring the biocoenoses studied. Accepting predation and recruitment as two of the most important factors for structuring the rocky subtidal community studied, Christie suggests the predators Coryphella sp., Asterias rubens and Psammechinus miliaris to be the most important key species. Hence a monitoring programme should concentrate on recording their abundance and effects on the recruitment success of coexisting organisms, especially of hydroids which were shown to exhibit the most pronounced abundance fluctuations. Hartnoll \& Hawkins monitored rocky-shore communities and recorded great inbuilt spatial and temporal variations. It remains to be seen whether pollution effects other than the most gross can

* See discussion in H. Barnes' paper which introduced the 1st European Marine Biology Symposium, pp. 25/26 (Helgoländer wiss. Meeresunters. 15, 6-26, 1967). 
be distinguished against such heavy background noise. Employing sediment transfer, Berge's studies on predation effects from unvegetated subtidal sediments, together with results from unvegetated intertidal mudflats, indicated to him that predation is of more limited importance for controlling subtidal community structure than has previously been reported from the intertidal.

J. C. R. Govaere et al. (pp. 507-521) studied benthic communities in the Southern Bight of the North Sea, focussing on structural parameters such as density, biomass and diversity. They found that the spatial stability of these parameters can be used for monitoring changes. Their data are too irregularly distributed in time to allow a critical assessment of temporal characteristics; however, diversity seems to be one of the most stable parameters for the macrobenthos as well as for the meiobenthos. Govaere et al. conclude that only large changes will be detected by ecological monitoring and that we are still far from understanding naturally occurring fluctuations in marine benthic communities.

E. Rachor (pp. 522-530) demonstrates that the majority of the benthic animals in the inner German Bight of the North Sea are very susceptible to environmental stress, especially oxygen deficiency. The communities involved must be considered ecologically sensitive and be protected from avoidable additional stress such as the introduction of man-made waste products. At present, the fauna suffers from oxygen depletion and $\mathrm{H}_{2} \mathrm{~S}$ formation, particularly in summer, and exhibits a continued trend of impoverishment.

Employing enzyme activity as essential criterion for determining whether a given organism is under stress from waste products, W. E. Pequegnat \& T. A. Wastler (pp. 531-545) studied the responses of their test organisms in field-installed Biotal Ocean Monitors (BOMs). Interested in long-term impacts, they use mitochondrial ATPase which reacts particularly to excess ambient biphenyls, catalase reacting to toxic metals, and cytochromes responding to cyclic and long-chain hydrocarbons. Also considered is the applicability of the adenylate energy charge (see next paragraph: Ivanovici). In essence, the methods employed are based on physiological bioassays that have been used with considerable success in medical research for years. They may not only open up new avenues for the ecologist, but could also help to solve a critical problem: it is neither feasible nor possible to determine the exact chemical composition of a water body or sediment which receives a large variety of pollutants; the total impact of the resulting medium, subsequent changes in pollutant identity and distribution, as well as synergistic effects of individual pollutants can only be assayed adequately and economically in toto - and just this is done by the field bioassay methods employed here. Enzyme activity has also been employed as criterion by J. Blackstock (pp. 546-555) using crude extracts of the polychaete Glycera alba. He suggests that the low phosphofructokinase activities in polychaetes from areas most severely affected by particulate organic industry effluent constitute a consistent biochemical response.

According to A. M. Ivanovici (pp. 556-565), measurement of adenylate energy charge (AEC), after overcoming some methodological limitations, may become a predictive tool for environmental management of aquatic organisms (invertebrates and vertebrates).The reductions in AEC, which occur in organisms stressed in various ways, indicate an augmented expenditure of metabolic energy reserves typical of stressed organisms (see also Theede, Gould, p. 735). Thus values of AEC correlate with defined 
physiological states which, in turn, signal the presence of stress. The present limitations of the method are outlined on p. 562.

As has been emphasized repeatedly, a major shortcoming of pollution-effect assessment is lack of baseline data regarding the original, unpolluted state. D. L. Tomlinson et al. (pp. 566-575) report heavy-metal concentrations from unpolluted Irish estuaries and suggest a natural baseline concentration of heavy metals in estuaries. They propose a "Biological Quality Index" and a "Pollution Load Index." D. Schmidt (pp. 576-586) monitored selected trace heavy metals in the southern North Sea and the western Baltic Sea. He discusses major differences and similarities between the histograms obtained from the two areas.

Genetic effects of marine pollutants have been examined by B. Battaglia et al. (pp. 587-595). Their 2-year analyses of Mytilus galloprovincialis populations revealed that at least some of the polymorphic loci detected undergo significant changes in gene frequencies which can be related to the degree of pollution in the sampling areas. Lower average heterozygosities and larger deficiencies of heterozygotes were recorded in most polluted areas examined. The results obtained appear to indicate that the test population in the most heavily polluted area is under strong selection with a well-defined trend.

\section{Management of areas, species and ecosystems}

Sessions on this topic were chaired by T. Levring, G. Persoone and G. Uhlig. After reviewing, discussing and critically evaluating management procedures in the Wadden Sea, W. J. Wolff \& J. J. Zijlstra (pp. 596-613) conclude that there is need for more integration of management measures. The present practice lacks effective coordination among countries in regard to economic, recreational and scientific interests. The Wadden Sea, a shallow sea area along the coasts of the Netherlands, the Federal Republic of Germany, and Denmark, covers a total area of some $8000 \mathrm{~km}^{2}$ and extends over more than $500 \mathrm{~km}$ of coastline. A typical sedimentation and mineralization basin with a large influx of organic matter, it is a highly productive nursery ground for numerous marine organisms, including commercially important fishes, migrating and wintering waders and water fowl. It features an oligospecific but rich benthic macrofauna and a delicate oxygen balance.

Man's activities in the Wadden Sea include shipping, military training, mining, waste discharge, recreation, fisheries, land reclamation, construction and scientific research. Considering management objectives, Wolff \& Zijlstra suggest that the best approach for coordinating man's often conflicting functions would be to rank the major activities in a hierarchical system, implying that a low-ranked activity should not (or only slightly) impair a higher-ranked activity. In this way nature conservation, fisheries and recreation (the "soft" functions) could best be protected, providing they are sufficiently highly ranked. That this does not solve all the problems involved is documented on pp. 607-610. Practically all countries concerned consider protection of the Wadden Sea a desirable and acceptable objective. Major human activities are now being evaluated in terms of their ecological impact, and scientists have started cooperative research efforts. However, the present practice of Wadden Sea management bears the 
characteristic of a preliminary measure. Definitive legislation and its translation into practicable management procedures is still lacking.

Two further examples of area management are presented by A. Thorhaug (pp. 614-623) and L. Fishelson (pp. 624-640). The former demonstrates the feasibility of rehabilitating and restoring a tropical seagrass community after severe damage due to a variety of man-made impacts. Following impact removal, replanting the dominant seagrass species (Thalassia testudinum) was successful and resulted in the re-establishment of essential fauna components within 4 years. Natural plant recruitment was much slower; Thorhaug estimates that 15 to 20 years would be required for achieving moderate plant densities (1500-2000 blades $\mathrm{m}^{-2}$ ). Reviewing studies on Red Sea corals in the shallow waters of the Sinai Peninsula, Fishelson calls attention to this unique and rich ecosystem which developed mainly after the last postglacial period. He emphasizes the need for continued protection of the area after its return to Egypt. Following detailed information on habitats and organisms, Fishelson proposes a variety of management procedures, including supervision by trained personnel and strictly enforced regulations for visitors.

The topic "Management of marine species" is introduced by P. Korringa's comprehensive paper (pp. 641-661). Drawing from decades of experience and forthrightly formulating his views on the matter, Korringa highlights the weak points of our present situation: "The fishery is not thinking in terms of consolidating its enterprises on a longterm basis, but is more interested in quick profit. Fishermen are not investors, but adventurers challenged by the presence of fish in the sea ..." (p. 657). In contrast, good management requires foresight, long-term planning and adequate application of scientific knowledge for wise exploitation of our natural resources. Scientists in the working groups of ICES continuously assess stock fluctuations of commercially important fish populations and warn the North-East Atlantic Fisheries Commission when overfishing threatens or is already evident. While the fishing industry is well aware of the advice of the fishery scientists, it "Just hopes that they may have been too pessimistic in their assessments. It has even been said that the quotas computed by the scientists of the Council have purposely been set too low ... It is easy to appreciate how much frustration such an unrealistic and ridiculous assumption will cause in the world of scientists" (p. 658).

In principle we have two choices: either to strive for good fishery management aiming at an optimum sustainable profit or to lose the high-grade fish and to exploit the low-grade ones for fish meal. The total fertility of an otherwise healthy marine environment can hardly be affected by present-day fishery. Thus the North Sea can be expected to continue to yield 2 to 3 million tons of fish each year. Permanent overfishing of the commercially most valuable species, however, will augment the stocks of opportunistic species of lesser commercial value. It is for the fishing industry to decide which way to go. However, should the choice be in favour of low-grade fish processed in the industrial fishery, considerably less marine protein will come to our tables.

Korringa exemplifies management - or mismanagement - of marine species by referring to a number of case studies involving the oyster, the blue mussel, the brown shrimp, the sole, the herring, the salmon and the bowhead whale. He closes his paper with a revealing assessment of ecological changes during the development from Zuyder Sea to Lake IJssel. In their famous and bold land reclamation and coastal protection 
programme the Dutch separated, in 1932, the Zuyder Sea from the North Sea by a huge dam. This "giant ecological experiment" has since facilitated a host of interesting observations.

J. W. Hedgpeth (pp. 662-673) considers man-made introductions of alien species into a given ecosystem. He concludes that in the majority of intentional or accidental introductions there is no clear understanding of the effects of such introduction on coexisting species. We lack adequate baselines of pre-introduction conditions and hence cannot appropriately assess the ecological consequences. Most introductions have failed, but several organisms - potentially harmful to native species or communities have succeeded all too well: "Provoking Mother Nature is a risky business" (p. 671). The recently developed concept of "mitigation," i.e. the artificial replacement of disturbed or destroyed areas by developing quasi-natural areas in compensation, has often been executed by inexperienced practitioners and has led to potentially dangerous introductions of exotic species. Hedgpeth illustrates the points made by referring to the striped bass Morone saxatilis, the oyster Crassostrea virginica, the gastropod Credipula fornicata, the crab Rhithropanopeus harrisii, the barnacle Elminius modestus and the shrimp Palaemon macrodactylus.

C. J. Sindermann (pp. 674-686) reviewed pollution effects on fisheries and considered actual as well as potential management activities. While pollution stress on fisheries has received considerable attention in recent decades, the information thus far produced is still insufficient for working out sound resource-management policies, except in local areas. It seems that in many cases factors other than pollution determine fish abundance, but we lack quantitative data for differentiating sufficiently between cause-and-effect relations of pollution and abundance. The basis for identifying pollution stress and for management is long-term monitoring of fish stocks: continuous assessment of stock dynamics and environmental conditions. There is much need for identifying and using reliable biological indicators of environmental degradation (e.g. unusually high levels of genetic and other anomalies in the earliest life-history stages; presence of pollution-associated diseases such as fin erosion and ulcers; biochemical/ physiological changes) and for reducing and controlling pollutant inputs. What we need most is a critical, carefully considered framework for responsible advice to political decision makers: "Scientists are on notice by environmental and resource managers to give them definitive information, or to withdraw to the laboratory and be very quiet" (p. 674).

Fisheries management in the Irish Sea, a relatively small enclosed area exposed to numerous man-made impacts (e.g. fishing, dumping of sewage and industrial sludge, discharges by nuclear power stations, gravel extraction, gas and oil prospecting, recreation), has been considered by K. Brander (pp. 687-699). To date, only fishing can be shown to have a clear, widespread effect on the ecosystem; it removes over half the adult populations of several commercial species each year. While the demersal fisheries continue to harvest high yields, there is little doubt that most species are overfished and at least one, Raia batis, has locally disappeared. In order to retain high sustained yields the fisheries are beginning to be managed by catch quotas and other means. But these will protect only a few commercial species and Brander suggests that a more comprehensive conservation policy is needed. He describes several studies which give information on long-term changes in fish populations (growth, mortality, recruitment, distribution) 
and, like Sindermann, emphasizes the need for such information in determining possible causes. ICES recommendations concentrate on single-species models. Brander criticizes their obvious shortcomings for an area of mixed fishery and high diversity such as the Irish Sea.

Large-scale plant harvesting can greatly affect marine ecosystems. P. J. S. Boaden \& M. T. Dring (pp. 700-710) found harvesting of the brown alga Ascophyllum nodosum, a major source of alginate, to cause significant and persistent damage to shore communities. While several littoral algae are of economic importance, the need is stressed to leave some fairly large intertidal areas unharvested. J. D. Pringle \& G. J. Sharp (pp. 711-720) identified detrimental harvesting consequences (largely Chondrus crispus but also some other marine plants). The development of detailed, protective resource management procedures requires the collection of many more baseline data.

In the USA, coastal habitat protection has now progressed to a point where management programmes are formulated for whole ecosystems. But J. Clark (pp. 721-731) emphasizes that management can succeed only if structural and dynamic features of the ecosystem involved are sufficiently known. A further limitation factor is the lack of professionals able to deal with ecosystem management. Such persons must not only have a broad ecological background, but must also be capable of devising practicable programmes, arranging compromises between conflicting interests and coordinating extremely varied activities. They must be generalists with a good scientific and administrative background. The feasibility of managing entire ecosystems varies widely along the US coastlines; it depends on economics, human population density, culture, politics and landform and requires conceptual subdivision of the ecosystem into subsystems. An example of integrated, practical coastal ecosystem management is Apalachicola Bay (pp. 721-731).

\section{CONCLUSIONS}

Far from being complete, this section focusses on some essentials presented and discussed during the symposium, offers some interpretations, and adds a few perspectives based on the author's own experience.

\section{Memorandum}

Deeply concerned by the still growing world-wide impact of human activities on the marine environment and its living components, the participants of the 14th European Marine Biology Symposium issued a memorandum. The text of the memorandum was formulated during and following the Informal Session on "Ocean Management," and subsequently made known to a number of scientific, administrative and political bodies immediately after the symposium. It reads as follows:

1. This symposium, attended by more than 200 scientists from 25 countries, is concerned at the continuing deterioration of the marine environment and its living resources, and at the inadequacy of the response of national authorities.

2. Marine habitat destruction and over-exploitation continue, areas of long established gross pollution still exist, while new field and laboratory data confirm the threat of longterm chronic pollution. 
3. The overall value of the seas to mankind is much underrated and, unless responsible management is focussed on protection of the oceans, future generations will be the poorer. Accordingly, we recommend that

(a) disposal of waste to the sea be further reduced and minimized by the development and use of new and existing technology;

(b) additional methods be developed to assess environmental health, the efficiency of protective measures and the effectiveness of legislation;

(c) scientific information already available be used to formulate and carry out adequate policies, and that scientists be more closely involved in the decision-making process.

4. The continuous nature of the world's oceans demands action on a national and international scale.

5. Effective measures should be undertaken to increase public awareness and involvement in the protection of life in the sea.

\section{The most dangerous pollutants}

The degree to which a certain type or group of pollutants can potentially endanger life in the sea depends, of course, on numerous factors and conditions. A statement regarding the most dangerous pollutants can, therefore, be made only in very general terms.

Of the pollutants considered during this symposium, pesticides and related chemical compounds constitute the greatest potential danger to life in the sea. These chemical compounds are largely or entirely foreign to the marine environment and often specifically designed to kill or incapacitate certain organisms (e.g. insects). The receiving ecosystems have no or only very limited capacities to metabolize, modify or degrade these substances. Hence, pesticides and related compounds tend to accumulate and to exert long-term effects. In most cases we cannot yet evaluate the full damage that may ultimately result. Although designed to act on selected target organisms, insecticides have been shown in numerous cases to be detrimental also to other forms of life. Every year, hundreds of new chemicals are produced. Many of these are discharged directly into the sea or finally enter it by various routes including rivers and atmosphere.

The major problems in assessing damage due to pesticides and related compounds are - in addition to the possible long-term effects already mentioned: (1) in-situ addition and combination of numerous different substances result in complex mixtures whose chemical properties and ecological consequences are difficult (if not impossible) to determine; (2) a number of physical, chemical and biological processes influence, modify or mask their original chemical identity and biological effectiveness; (3) although a number of specific analytical methods are now available, exact chemical identification of individual substances in the field remains problematic.

Heavy metals rank second as potential hazards to life in the sea, particularly near the coast. Mercury, cadmium and lead are especially dangerous to marine life and public health. Copper, zinc, silver and chromium have also been shown to cause significant damage. While critical studies on possible long-term effects have still to be conducted, there is, at present, little or no unequivocal evidence for irreversible damage at the ecosystem level. 
Present levels of radioactive marine pollution are largely considered to be significantly below potentially detrimental threshold values. However, the total amount of tritiated water released into the sea is rapidly increasing. Oil, oil dispersants and related substances have thus far caused damage that has turned out to be quite limited in space and time and to be reversible at the ecosystem level. The ecological significance of "pollution-made" pheromones which may interfere with interorganismic communication and mechanisms of ecosystem integration requires further analysis. Pulp and paper industry wastes also tend to cause limited and reversible effects - mainly distortions in oxygen and nutrient budgets. Adequately controlled, pulp and paper wastes - as well as domestic pollutants - may even enhance the local commercial fishery yield, providing the total carbon input does not exceed the carrying capacity of the receiving ecosystem.

Pollution due to other sources - especially construction and mining - has thus far not caused severe damage, except in specific cases and locations. Here, dam-building, power-plant cooling and deep-ocean mining can cause restricted distortions. Major damage may, however, result from large-scale mining due to habitat destruction and sediment transport.

While this brief overview may suggest less damage than has often been predicted, it neglects possible accumulative, synergistic pollutant effects and the fact that life in the sea is endangered not only by pollution, but also by other activities of man, such as large-scale collection and removal of certain organisms (fisheries), and by mixing of originally separate ecosystem components (translocation of organisms, e.g. due to navigation or aquaculture). In fact all activities of the very large and rapidly growing human population tend to affect our environment in one way or another. They all tend to destabilize ecosystems and to accelerate energy degradation, and thus add to the difficulties encountered by ecologists analysing ecosystem dynamics, differentiating between natural and man-made effects on the biota, and developing pollution-effect forecasting capabilities.

\section{The most endangered areas}

Without doubt, the most endangered sea areas are those near the coast, i.e. those close to the primary source of the danger: man. Of major concern are estuaries, especially if located in highly industrialized countries, and enclosed sea basins (e. $\mathrm{g}$. Baltic and Mediterranean Seas) with little water exchange. Economically, rivers and estuaries are considered attractive sites for industrial plants in terms of trade, traffic and pollutant release. However, ecologically they are entirely unsuitable as pollutant receivers because they tend to retain, trap and accumulate pollutants in their sediments and because they have, together with other coastline habitats, a number of important functions in supporting life of adjacent marine and terrestrial habitats.

\section{Principal criteria for assessing pollution effects}

Pollution effects manifest themselves in abiotic and biotic ecosystem components. Both are interrelated in many ways and must be considered together. However, in the present context, we only refer to biotic components - the marine organisms concerned. Here we can distinguish (1) the kinds, concentrations and distributions of pollutants 
within the body, (2) the effects of these and ambient pollutants on organismic functions and structures. The analysis of pollutant identity, concentration and distribution within the body is largely a matter of analytical chemistry and anatomical knowledge; the assessment of biological effects is the domain of the ecologist.

The ecologist concerned with the assessment of pollution effects on life in the sea encounters four major difficulties: (1) differentiation between natural and pollutioncaused changes; (2) determination of effects due to pollutants acting in concert $;$ (3) exact identification and correlation of cause and effect; (4) selection of reliable criteria which are readily measurable and which facilitate a precise diagnosis of the ecological status.

These difficulties are magnified because various compensation mechanisms tend to mask the effects and to render them measurable only after often considerable lag periods, i.e. after the organism's compensatory capacities begin to fail. Presumably this happens long after the initial impact and primary damage occurred. The degree of system complexity, the sum total of the compensation mechanisms available and hence the diagnostic difficulties increase from the individual level to the ecosystem level.

Individuals respond to environmental stress long before stress symptoms become demonstrable at the population or ecosystem levels. Hence it is here that we must look for early warning signals. On the other hand, responses measured at the individual level do not lend themselves readily to interpreting and predicting changes at the ecosystem level. Many gaps in our present knowledge need to be filled before extrapolations from the individual to the ecosystem level can be made with some degree of reliability.

\section{Criteria at the individual level}

Criteria at the individual level include mortality, rates of growth, metabolism, activity and reproduction, reduced resistance to environmental stress or disease, plus a variety of general stress manifestations involving behaviour as well as enzyme, hormone and energy dynamics. Important reviews on pollution effects on marine organisms have been presented, for example, by Goldberg (1972), ICES (1978), Ruivo (1978) and Cole (1979). The suitability of organisms as indicators of pollution has received attention from Phillips (1977) and, in a more general way, from Kinne (1977b).

Measuring death as end point, mortality is a crude criterion. But it facilitates a quick general assessment of pollutant toxicity. Mortality tests operate under extreme conditions which permit survival only for minutes, hours or days. The advantage of such conditions is that the test organisms cannot activate their compensation mechanisms. Hence the impact acts directly and swiftly, and cause and effect can be related without much complication. While mortality tests usually yield reliable and reproducible results and do not require complicated equipment, comprehensive, statistically sound test series employing numerous sequential lethal doses have their own problems. Ecologically, the death of an individual is largely irrelevant. What counts here most are changes in competitive performance of coexisting groups of organisms and flow patterns of energy and matter at the ecosystem level.

Differences in organismic performance can be analysed by employing criteria such as rates of growth, metabolism, activity and reproduction. These are standard criteria generally applied by experimental ecologists and hence need no specific attention here. 
Less often used, but ecologically very significant, are criteria measuring the degree of resistance to environmental stress (e.g. Kinne, 1970, 1971, 1972) and/or disease predisposition (e.g. Kinne, 1980).

Except for mortality, all criteria listed above yield demonstrable symptoms only after considerable delay due to the counteractive potentials of a variety of compensation mechanisms (Fig. 1). This fact often leads to an underestimation of the pollution impact and to declaring a given stress as "subcritical" or "non-dangerous," while in reality the target organism already encounters critical deformation which is bound ultimately to change or reduce its ecological potential (cryptic response, delayed damage).

Changes in behaviour comprise a different set of criteria. Many marine organisms exhibit, for example, remarkable abilities for obtaining and interpreting information about their environment by olfaction and gustation. Usually measurable in terms of behavioural changes, such abilities provide the most sensitive response patterns yet available. However, recognition of pollutant gradients and damage due to pollution are two quite different things. In addition, olfactory adaptation significantly modifies the response levels and hence ad-hoc discrimination capacities. But then there are numerous other behavioural responses which await investigation into their possible value as indicators of pollution stress.

For the future, critical research into enzyme, hormone and energy dynamics is likely to open up promising perspectives for detecting new, important, early-warning criteria. The study of general, usually unspecific, stress phenomena which precede conventional

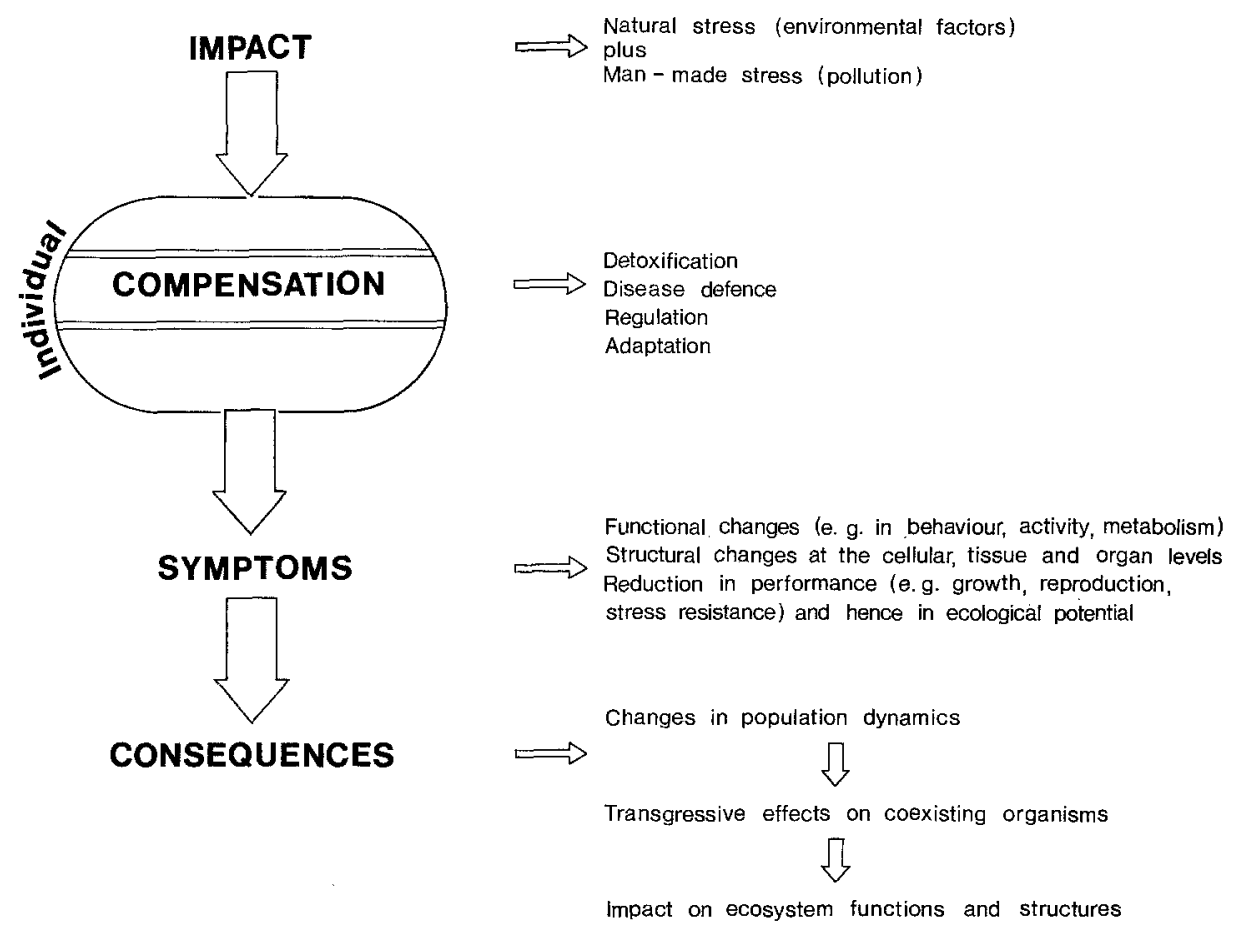

Fig. 1. Environmental impact: responses at the individual level 
symptoms of disease manifestation begins to attain a high priority in modern medicine. Here lies a wide, fertile field for the pollution researcher and for interdisciplinary cooperation between medicine and ecology. Examples for criteria at the enzyme level have been considered by Pequegnat \& Wastler (pp. 531), at the energy level by Ivanovici (pp. 556).

\section{Criteria at the ecosystem level}

Criteria for assessing pollution effects at the ecosystem level are: changes in species composition, diversity, abundance and distribution (ecosystem structures), and changes in flow rates and routes of energy and matter (ecosystem functions). Different structural and functional states of ecosystems which may serve as criteria were considered in the proceedings of the International Helgoland Symposium on "Ecosystem Research" under the terms efficiency, maturity, resistance to deformation, stability, healthiness and diversity (Kinne, 1977a).

Due to very pronounced and highly elastic compensatory capabilities, pollution impact on ecosystems - acting through the changes imposed at the individual level - is even more difficult to recognize and to diagnose than in individuals. The theoretical sequence of pollution effects at the ecosystem level is illustrated in Figure 2.

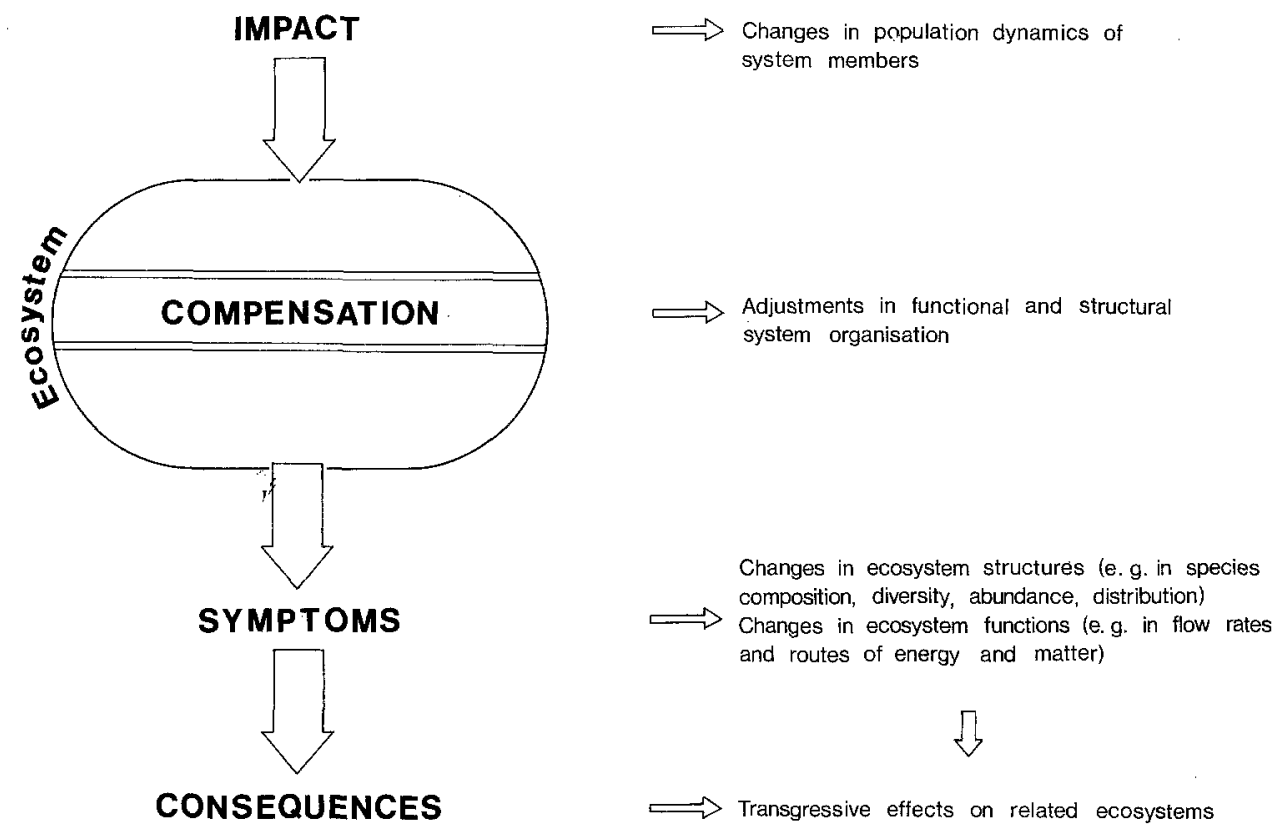

Fig. 2. Environmental impact: responses at the ecosystem level

Of particular significance as criteria for assessing pollution effects at the ecosystem level are diversity and stability. A number of predictive models employing these criteria have produced interesting and encouraging results.

Progress in assessing pollution effects at the ecosystem level requires first of all 
more solid data on environment-related organismic performance at the individual and population levels and of ecological dynamics in the sea. In addition, we must develop new analytical concepts. I wish to consider briefly three potentially useful concepts which I introduced many years ago and which now seem to require reemphasis: the concepts of physiological and ecological potential and ecological existence, and the concept of ecological species diagnosis (Kinne, 1952, 1953, 1956, 1957a, b; see also 1976, pp. 8,9).

The physiological potential of a species comprises its capacity to perform and to respond under conditions essentially unlimited by interspecific relations and competitive restrictions. The physiological potential is determined in laboratory experiments, i.e. after isolation of the test organism from interfering coexisting organisms under a variety of different, ecologically relevant environmental and nutritive conditions. The e cological potential of a species comprises its capacity to perform and respond under in-situ conditions, i.e. in concert with coexisting organisms such as competitors, predators and disease agents. The ecological potential is assessed in comparative field studies or in multispecies experiments. The e cological exis t e $\mathrm{n} \mathrm{e}$ is that portion of the ecological potential which is actually realized under a given set of ecological conditions. While somewhat reworded and condensed, these definitions characterize the essence of the concepts concerned.

Let us consider a situation in which the physiological potential exceeds the ecological potential. Extent and type of such a difference are then indicative of stress factors operative under field conditions. In contrast, an ecological potential which exceeds the physiological potential indicates the existence under field conditions of supporting factors lacking or less pronounced during isolation in the laboratory experiment (e.g. growth substances, symbionts, other favourable interspecific relations): Congruence between physiological and ecological potentials demonstrates the absence of modifying factors. Of course, basic prerequisites for such conclusions are adequate culture conditions.

The ecological species diagnosis (Kinne, 1957b) is a concept which parallels that of the taxonomic species diagnosis. But it leads to a different classification of organisms. While taxonomic groupings are based largely on common evolutionary roots and similar structures, the ecological species diagnosis leads to taxa with similar ecological requirements and capacities, i.e. with similar physiological and ecological potentials. Characteristics which qualify as criteria for an ecological species diagnosis are, for example, type of feeding mechanism, nutritional requirements, trophic position, rates of metabolism, growth and reproduction, degree of environmental resistance (e.g. to temperature, salinity, oxygen levels, pollutants), body size, length of life, degree of steno- or eurytopy or of opportunism, etc. Comparative studies of ecological species diagnoses and of ecological taxa facilitate the analysis of ecosystem structures and functions, of the exchangeability of system members and hence of ecosystem homeostasis, and of the amount of stress encountered by an ecosystem. It can thus help to formulate general ecological principles.

In 1952 and 1956, I formulated the following general principles which, in the meantime, have been supported by some evidence.

(1) Species which exhibit a high degree of resistance (are euryplastic) to variations in abiotic factors (e.g. temperature, salinity, pollutants) tend to exhibit a low degree of 
resistance (are stenoplastic) in regard to biotic factors (e.g. competition, biotic disease predisposition) and vice versa.

(2) Abiotically euryplastic species tend to occupy habitats in which abiotic factors attain critical intensities and thus assume control of organismic proliferation and distribution (example: estuaries). In contrast, abiotically stenoplastic species tend to be restricted to habitats with physically stable conditions; here population dynamics are primarily controlled by biotic factors (example: coral reefs).

(3) In general, euryplastic species are characterized by lower rates of growth, metabolism and reproduction. Under comparable conditions the euryplastic Gammarus duebeni, for example, grows more slowly, has lower respiratory rates and produces fewer offspring per female than its more stenoplastic competitor G. zaddachi. As long as environmental conditions remain suitable for $G$. zaddachi this amphipod tends to outcompete and to displace $G$. duebeni. But sporadically returning stress conditions (e.g. extreme temperatures, salinities) effectively reduce its population strength and thus allow G. duebeni to recover ground. Such a relationship appears to represent a principal ecological phenomenon which, in a 1956 lecture, I summarized in the statement "In terms of ecological strategy you can either be fast but easily hurt, or slow but resistant". Returning to environmental protection: species and ecosystems with high rates of metabolism and turn-over are more vulnerable to pollution than are low metabolic-rate systems.

Habitats with stable abiotic conditions of intermediate factor intensities, inhabited to a large extent by euryplastic species, are indicative of prevailing pollution impact. Also reductions in the number of long-lived species, diminutions in species diversity and distortions in food-web relations provide - in the absence of unusual natural stress criteria and evidence for pollution impact at the ecosystem level. On the other hand, a high percentage of stenoplastic species and a high species diversity are characteristic of unpolluted or sub-critically polluted ecosystems. And so is a complex flow pattern of energy and matter with numerous built-in alternative routes. These provide for a high compensatory potential and hence a high degree of ecosystem stability.

In economical terms, euryplastic species are often less vulnerable than the so-called "climax species" (e.g. commercially used large crustaceans and fishes) near the top of the food pyramid. They are characteristic of mature ecosystems that developed under environmental conditions favourable to numerous organisms and that had sufficient time to attain a climax state of diversity and stability.

\section{Pollution control and environmental management}

Modern technology is capable of treating domestic wastes to drinking-water quality and of treating the vast majority of industrial wastes to non-toxic levels. The remaining dangerous substances can be selectively retained, recycled or stored. Thus the central problem of pollution control is not so much our technical capacity for avoiding critical pollution, but the high, sometimes forbidding costs involved. This holds also for the degree of safety in the transportation of potentially hazardous pollutants such as oil.

Society must decide how much it is prepared to pay for pollution control and environmental management in the light of economic considerations and protective requirements. In order to define the latter, a decision must be made in regard to the 
ultimate goal. What exactly do we wish to protect and how much pollution is permissable without risking critical damage to the target of protection? The answers to these crucial questions vary with the perspective of the responding authority. The chances for general agreement suffer from diverging interests in the uses of the sea and from insufficient ecological knowledge about life in the sea and its tolerance limits to manmade disturbances.

Many authorities concerned with pollution control in the sea aim at reducing the impact of marine pollution to levels compatible with continued exploitation. The pollution impact is considered permissable as long as the fisheries, for example, can sustain their harvest. In my opinion, such "management of use-interests" is insufficient and dangerously short-sighted from an ecological point of view. While providing a host of data, fishery-landing statistics are a questionable criterion for assessing ecological pollution effects. They have an insufficient early-warning capacity. In addition, reliable data are often difficult to come by - for a variety of reasons including commercial competition - and the fishermen's primary interest in quick profit obscures their ability to recognize sound long-term requirements for environmental protection (p. 747: Korringa). Fisheries utilize the sea - as do industry, tourism, recreation services, etc. As such they have an important role to play in resource partitioning, but the definition of safety limits for the protection of life in the sea must be a matter for scientists free of direct commercial interests and pressures.

As has been pointed out repeatedly during this symposium, it cannot be the aim of pollution control to conserve specific functions or structures of ecosystems as they exist today. Ecosystems have always changed and will continue to do so. We must attempt to define those functions and structures of ecosystems which are essential for the continued support of civilized human life (p. 734). As long as scientific knowledge is insufficient for an exact definition of such properties, maintenance of a high degree of organismic and environmental diversity and the conservation of natural conditions, at least in certain areas, is considered necessary. A large diversity of gene pools and habitats, as well as the establishment of especially protected, ecological key areas, is at present a must for reducing the risk of irreversible overall damage.

The most obvious and most effective means of pollution control is ad-hoc treatment of objectionable pollutants within the production plant. Production engineers must be encouraged to develop integrated at-the-source pollution controls. The safety of all new products and concomitant wastes to man and marine organisms should be evaluated by the producer prior to mass production and release (e.g. Duthie, 1977; Kimerle et al., 1977; Cairns et al., 1978).

Increasing costs of waste discharge are likely to enforce careful selection of production materials, as well as possibilities for product recovery and re-utilization. In addition, optimization of pollutant-dispersal systems, along with discharge timing (sequence, daytime, season) and localization (site selection based on ecological knowledge), can help to reduce the pollution impact.

Fortunately, several international conventions for the prevention of marine pollution (e.g. Oslo, London, Paris Conventions) now prohibit the dumping of particularly dangerous substances, such as organohalogen compounds, organosilicon compounds, mercury and mercury compounds, cadmium and cadmium compounds, persistent plastics, crude oil, high-level radioactive substances, materials produced for biological and chemical 
warfare. For a number of other wastes special permits are required. If rigidly controlled such banning of hazardous substances is a most significant contribution to marine pollution control.

In regard to environmental management (for definition consult p. 734), we can distinguish four principal categories: management of areas, resources, species and ecosystems.

\section{Management of areas}

Management goals and capabilities depend on size, location and ecological characteristics of the area concerned. For simplicity we distinguish here three aspects: local, regional and global.

The local aspect focusses on areas near the land/sea boundary: estuaries and coastal waters. Closest to man's major activities, these waters are presently prime targets of marine construction, waste-water discharge, exploitation and recreation. At the same time, these waters are also particularly suited for management procedures: they often lie within national boundaries and jurisdiction; they are restricted in size and hence are controllable.

Ecologically, estuaries and coastal waters tend to support ecosystems under considerable abiotic stress (e.g. extreme intensities and variations in temperature, salinity, oxygen level, turbidity). Hence, additional stress due to pollution may quickly lead to critical impact levels. For these regions, safety levels must be set high - much higher than laboratory resistance tests with euryplastic estuary inhabitants would generally indicate.

The regional aspect focusses on larger coastal or semi-enclosed sea areas within the jurisdiction of two or more countries. Examples are the North Sea, Baltic Sea and Mediterranean Sea. Here management problems arise because of often diverging national interests and financial means and more complex legal problems of control.

The global aspect involves the open seas. Here management is practically limited to dumping restrictions, i.e. to the control of pollutant release. Politically, global agreements on pollution control are difficult to achieve and technically they are difficult to enforce and control. Ecological knowledge on life in the open sea is generally less advanced than near the coasts. Deep-sea and polar regions, while presumably especially vulnerable to pollution impact, await more thorough investigations.

Area management requires (1) recording of the different types of uses involved and of their intensities and areal coverage; (2) assessment of, and legislative ruling on, useconflicts; (3) studies of use-impacts and definition of safety levels; (4) enforcement and control of safety requirements. Concerned primarily with Point (3), the ecologist must determine water-quality standards, and monitor a variety of biological criteria and symptoms in order to recognize and control critical impact limits.

\section{Management of resources}

The principal aims of resource management are coordination and optimization of use-interests without jeopardizing - where possible even improving - continued resource exploitability.

While use-conflicts are a matter of administrative politics, ecological know-how is required for assessing potential impacts on living resources and hence for formulating management goals. In most cases, the major sources of use-damage are non-degradable 
chemical wastes which are foreign to the system, irreversible changes due to construction, mining, dredging, filling and water-flow regulations, and overfishing. Critical impacts may, in certain situations, also arise from aquaculture installations, land reclamation and recreation. All three can lead to habitat modification or destruction. Quantification of impact and safety limits is usually difficult. The requirements by, and potential damage from, industry-related impacts can often be assessed, at least in general terms; this is more difficult with respect to aesthetic or ecosystem damage.

\section{Management of species}

The management of species aims at protecting populations of certain organisms from critical human interference - typically due to excessive hunting and fishing, but also to habitat diminution or destruction, interruption of life-cycle dynamics (dambuilding), etc. A few commercially used turtles, fishes and whales, for example, have become so diminished in population strength that their survival appears threatened, and a number of other marine animals - including birds - are increasingly encountering difficulties in finding adequate and sufficient-sized areas for breeding and feeding. True, overfishing does not seem to have thus far led to the extinction of a species. But also true: protection from extinction was not achieved in these cases by management procedures. Critical decrease in abundance simply rendered the ratio yield to fisheries effort uneconomical. With technological advances in fishing methods, such built-in protection may not always be sufficient, but must be replaced by planned management.

Protective species management must first of all determine and control man's impact due to direct exploitation. It must secondly assess indirect consequences of man's activities leading, for example, to quality reductions of breeding and feeding areas or to increased ecological potentials of competitors or disease agents. And it must thirdly weigh the impact of all these influences against pre-existing baseline stress (i.e.

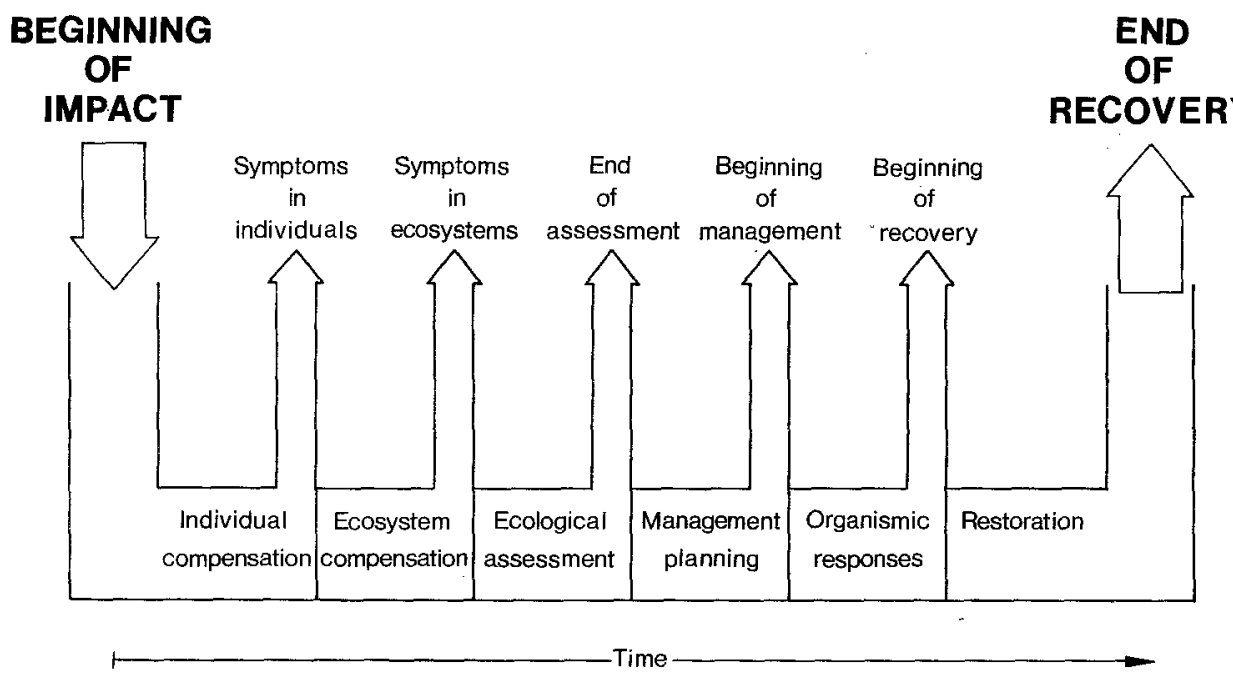

Fig. 3. Management of ecosystems: major time-lag events 
intensities of natural abiotic factors) encountered by the species concerned. The simplest type of protective species management is the removal and reduction of overfishing impact. This "simply" requires administrative decision and control.

\section{Management of ecosystems}

Most important for man's long-term survival, ecosystem management remains problematic. Aims, ends and principles are difficult to define. We are just in the process of attempting to build the necessary scientific framework, and the political difficulties seem, at present, unsurmountable. Man's egotism and interest conflicts allow only unequivocal evidence of critical damage to be transformed into effective political action. But such evidence is likely, at least for the present time, to remain unobtainable prior to severe damage.

A potentially tragic chain of circular argumentation (see Lewis,p. 463) and a series of time-lag events (Fig. 3) overshadow our chances of correcting ecosystem damage quickly and effectively enough for preventing an irreversible breakdown of essential man-supporting system qualities. The often-heard argument "We cannot act unless ecologists present hard facts on which our action can be based" is unrealistic. Ecologists may in fact never be in the position to provide the kind of solid data presently asked for by politicians. Ecosystem dynamics may turn out to be too complex and too unpredictable to bring sufficient light into its machinery for reliable forecasting of impact consequences at the ecosystem level.

\section{LITERATURE CITED}

Cairns, J. Jr., Dickson, K. L. \& Maki, A. W. (Eds), 1978. Estimating the hazard of chemical substances to aquatic life. American Society for Testing and Materials, Philadelphia, $278 \mathrm{pp}$.

Cole, H. A., 1979. Marine pollution - facts and fiction, the situation in Britain. - Ocean Management $5,263-278$.

Duthie, J. R., 1977. The importance of sequential assessment in test programs for estimating hazard to aquatic life. - In: Aquatic toxicology and hazard evaluation. Ed. by F. L. Mayer \& J. L. Hamelink. American Society for Testing and Materials, Philadelphia, 17-35.

Goldberg, E. D. (Ed.), 1972. Baseline studies of pollutants in the marine environment and research recommendations. IDOE Baseline Conference, 24-26 May, New York.

Goldberg, E. D., Gamble, E., Griffin, J. J. \& Koide, M., 1977. Pollution history of Narragansett Bay as recorded in its sediments. - Estuar, coast. mar. Sci. 5, 549-561.

ICES, 1978. On the feasibility of effects monitoring. - Coop. Res. Rep. 75, 1-42.

Kimerle, R. A., Levinskas, G. J., Metcalf, J. S. \& Scharpf, L. G., 1977. An industrial approach to evaluating environmental safety of new products. In: Aquatic toxicology and hazard evaluation. Ed. by F. L. Mayer \& J. L. Hamelink. American Society for Testing and Materials, Philadelphia, 36-43.

Kinne, O., 1952. Experimentelle Untersuchungen zur Biologie, Ókologie und Physiologie von Gammarus duebeni Lillj. Ein Beitrag zur Kenntnis der Brackwasserorganismen. Diss., Univ. Kiel. $186 \mathrm{pp}$.

Kinne, O., 1953. Zur Biologie und Physiologie von Gammarus duebeni Lillj. I. - Z. wiss. Zool. 157, $427-491$.

Kinne, O., 1956. Über den Wert kombinierter Untersuchungen (im Biotop und im Zuchtversuch) für die ökologische Analyse. - Naturwissenschaften 43, 8-9.

Kinne, O., 1957a. Physiologische Ökologie - ein modernes Forschungsgebiet. Gedanken zur Problematik und Methodik der Okologie. - Biol. Zbl. 76, 475-485.

Kinne, O., 1957b. A programmatic study of comparative biology of marine and brackish water animals. - Anńls Biol. 33, 87-92. 
Kinne, O., 1968. International symposium "Biological and hydrographical problems of water pollution in the North Sea and adjacent waters": Closing address. - Helgoländer wiss. Meeresunters. 17, 518-522.

Kinne, O. (Ed.), 1970. Marine ecology. Wiley-Interscience, London 1 (1), 1-681.

Kinne, O. (Ed.), 1971. Marine ecology. Wiley-Interscience, London 1 (2), 683-1244

Kinne, O. (Ed.), 1972. Marine ecology. Wiley-Interscience, London 1 (3), 1245-1774

Kinne, O. (Ed.), 1976. Marine ecology. Wiley-Interscience, Londen $3(1), 1-577$.

Kinne, O., 1977a. International Helgoland Symposium "Ecosystem research": Summary, conclusions and closing. - Helgoländer wiss. Meeresunters. 30, 709-727.

Kinne, O., 1977b. Cultivation of animals. Research cultivation. In: Marine ecology. Ed. by O. Kinne. Wiley-Interscience, Chichester 3 (2), 579-1293.

Kinne, O., 1980. Diseases of marine animals: General aspects. In: Diseases of marine animals. Ed. by $\mathrm{O}$. Kinne. Wiley-Interscience, Chichester 1, 13-73.

Kinne, O. \& Aurich, H. (Eds), 1968. Internationales Symposion "Biologische und hydrographische Probleme der Wasserverunreinigung in der Nordsee und angrenzenden Gewässern". - Helgoländer wiss. Meeresunters. 17, 1-530.

Phillips, D. J. H., 1977. The use of biological indicator organisms to monitor trace metal pollution in marine and estuarine environments - a review. - Envir. Pollut. 13, 281-316.

Ruivo, M. (Ed.), 1978. Marine pollution and sea life. Fishing News Books Ltd, West Byfleet, Surrey, $624 \mathrm{pp}$. 